\title{
PENGARUH DISIPLIN KERJA, BUDAYA ORGANISASI DAN PEMBAGIAN KERJA TERHADAP PRODUKTIVITAS KERJA BADAN PENDAPATAN DAERAH PROVINSI BANTEN
}

\author{
Prihastuti Listiowati \\ Institut IImu Sosial dan Manajemen STIAMI \\ e-mail: prihastutilistiowati@gmail.com
}

\begin{abstract}
Abstrak, tujuan dari penelitian ini adalah untuk menganalisis dan mengevaluasi seberapa besar pengaruh disiplin kerja terhadap produktivitas kerja, untuk menganalisis dan mengevaluasi seberapa besar pengaruh budaya organisasi terhadap produktivitas kerja, untuk menganalisis dan mengevaluasi seberapa besar pengaruh pembagian kerja terhadap produktivitas kerja, untuk menganalisis dan mengevaluasi seberapa besar pengaruh disiplin kerja, budaya organisasi dan pembagian kerja terhadap produktivitas kerja. Teori disiplin kerja yang digunakan dalam penelitian ini mengacu pada pendapat Sutrisno, teori budaya organosasi yang digunakan dalam penelitian ini mengacu pada pendapat Ardana, teori pembagian kerja yang digunakan dalam penelitian ini mengacu pada pendapat Sutarto, dan teori produktivitas kerja yang digunakan dalam penelitian ini mengacu pada pendapat Simamora

Metode penelitian yang digunakan adalah metode kuantitatif melalui penyebaran kuesioner, dengan jumlah populasi sebesar 78 dan sampelnya adalah 78 orang responden (sampel jenuh)

Berdasarkan hasil penelitian dengan menggunakan analisis regresi linier berganda dengan bantuan SPSS versi 24 menunjukan bahwa terdapat pengaruh signifikan disiplin kerja terhadap produktivitas kerja pada Badan Pendapatan Daerah Provinsi Banten sebesar $15,3 \%$, terdapat pengaruh signifikan budaya organisasi terhadap produktivitas kerja pada Badan Pendapatan Daerah Provinsi Banten sebesar 49,8\%, terdapat pengaruh signifikan pembagian kerja terhadap produktivitas kerja pada Badan Pendapatan Daerah Provinsi Banten sebesar 17,7\%, dan terdapat pengaruh signifikan disiplin kerja, budaya organisasi dan pembagian kerja secara bersamasama terhadap produktivitas kerja pada Badan Pendapatan Daerah Provinsi Banten sebesar $82,9 \%$ sisanya $17,1 \%$ merupakan faktor lain yang tidak diteliti
\end{abstract}

Kata kunci : disiplin kerja, budaya organisasi, pembagian kerja, produktivitas kerja

\section{LATAR BELAKANG PENELITIAN}

Era globalisasi menuntut adanya kompetensi dari semua pihak untuk saling bersaing guna memperebutkan kedudukan tertentu dalam bidang ekonomi, sosial, budaya maupun politik. Perubahan tersebut membawa dampak pada perubahan budaya organisasi, yang mau tidak mau harus dihadapi serta serangkaian adaptasi juga harus dilakukan terhadap keberagaman (diversitas) yang mengacu pada perbedaan atribut demografis seperti ras, kesukuan, gender, usia, status, fisik, agama, pendidikan, atau orientasi seksual.

Selain keberagaman (diversitas), tantangan yang cukup kompleks adalah bagaimana mengubah budaya organisasi lama yang sudah tidak sesuai lagi dengan nilai-nilai budaya organisasi pada seluruh pegawai atas keinginan secara sukarela dan partisipasi pegawai.

Budaya organisasi adalah kebiasaan yang dilakukan berulangulang oleh pegawai dalam suatu organisasi. Pelanggaran terhadap 
kebiasaan ini memang tidak ada sanksinya yang tegas, namun dari pelaku organisasi secara moral telah menyepakati bahwa kebiasaan tersebut merupakan kebiasaan yang harus ditaati dalam rangka pelaksanaan pekerjaan untuk mencapai tujuan organisasi. Budaya organisasi akan bermanfaat dalam suatu organisasi manakala masingmasing pegawai saling memberikan sumbang saran dari teman-teman sekerjanya, namun budaya organisasi itu akan berakibat buruk apabila pegawai dalam sebuah organisasi tersebut mengeluarkan egonya masing-masing karena berpendapat bahwa dia dapat bekerja sendiri tanpa bantuan orang lain.

Badan Pendapatan Daerah (Bapenda) Provinsi Banten saat ini masih jauh dari apa yang diharapkan oleh pemerintah daerah. Ini terlihat dari beberapa masalah yang menunjukkan belum tumbuhnya kesadaran optimal untuk membangun budaya organisasi yang positif, diantaranya : masih ada pegawai yang belum melaksanakan tupoksi dengan baik; misalkan mengerjakan pekerjaan yang bukan urusan dari Badan di jamjam bekerja, pegawai lebih suka bersantai-santai daripada bekerja; ini terlihat ketika jam masuk bekerja, pegawai lebih mendahulukan berbincang-bicang dengan pegawai lain membicarakan hal-hal yang bukan urusan pekerjaannya, dan budaya organisasi akan bermanfaat dalam organisasi manakala masing-masing pegawai saling membutuhkan sumbang saran dari teman sekerjanya, dan menjadi berakibat buruk apabila pegawai tersebut mengeluarkan egonya masing-masing, dan cenderung membuat kinerja pegawai tidak maksimal

Keberhasilan organisasi pada umumnya diukur dari produktivitas dan efektivitas pelaksanaan tugas-tugas yang dilaksanakan dengan efektif, maka ia disebut sebagai organisasi yang berhasil. Sebaliknya bila produktivitas menurun dan organisasinya dinilai tidak efektif dalam jangka waktu tertentu, maka disebut organisasi yang gagal.

Dalam rangka pencapaian efektivitas pelaksanaan tugas tersebut, organisasi pada umumnya dihadapkan pada beberapa tantangan-tantangan, antara lain tantangan untuk meningkatkan kualitas dan kemampuan sumber daya manusia secara berkesinambungan untuk mempertahankan kesinambungan kelangsungan hidup dan meningkatkan kemajuan organisasi serta mampu bersaing dengan organisasi lain, tantangan untuk menumbuhkan nilai kesadaran, semangat kerja dan partisapasi bawahan dalam meningkatkan produktivitasnya, guna tercapainya efektivitas dalam pelaksanaan tugas, dan tantangan menghadapi globalisasi dalam bidang ekonomi, ilmu pengertahuan dan teknologi, khususnya teknologi informasi yang dapat menimbulkan terjadinya perubahan dan pergeseran, baik terhadap peruibahan pribadi maupun organisasi, sehingga organisasi khususnya organsasi pemerintah ditantang untuk semakin meningkatkan efisiensi dan efektivitas dalam upaya memberikan layanan yang memuaskan kepada masyarakat.

Kondisi suatu organisasi, baik organisasi milik pemerintah maupun swasta, bila kondisi psikologis pegawai kurang menunjang. Maka akan berpengaruh terhadap efektivitas kegiatan organisasi, terlebih lagi bila kondisi tersebut berasal dari organisasinya itu sendiri, hal tersebut akan berpengaruh terhadap keberhasilan pencapaian tujuan dan sasaran yang telah ditetapkan. 
Dalam suatu organisasi, walaupun uraian tugas telah diatur dengan jelas sebagaimana diatur dalam tugas pokok dan fungsi organisasi kurang, bila pegawai kurang bergairah, menyebabkan kinerja pegawai menjadi kurang baik, sehingga produktivitas menurun, yang pada gilirannya pelaksanaan tugas tidak tercapai sesuai dengan yang direncanakan.

Kurangnya produktivitas kerja pegawai dapat disebabkan oleh beberapa hal yaitu : kurang tanggapnya pimpinan dalam merespon ide-ide dan prakarsa yang berasal dari bawahan, terlalu banyaknya tugas dan pimpinan selalu memaksakan perintahnya, sehingga bawahan tidak mempunyai kesempatan waktu untuk mengeluarkan pendapat dan kreativitasnya, rendahnya pengamalan budaya organisasi, dan rendahnya loyalitas pegawai

Belum tercapainya efektivitas pelaksanaan tugas sebagai akibat kurangnya budaya organisasi dan disiplin kerja sudah barang tentu akan mengecewakan berbagai pihak, terutama bagi organisasi tersebut. Sehubungan dengan kondisi tersebut di atas, penulis mengadakan pengamatan terhadap satuan organisasi pemerintah yaitu Badan Pendapatan Daerah Provinsi Banten.

\section{Berdasarkan}

pengamatan

penulis, sementara ini tingkat disiplin, budaya organisasi dan pembagian kerja masih perlu ditingkatkan, hal ini dapat diamati dari motivasi pegawai masih rendah, hal ini ditandai dengan masih adanya pegawai yang datang terlambat, meninggalkan tempat kerja untuk kepentingan pribadi tanpa ijin atau sepengetahuan atasan, tidak masuk kerja dengan berbagai alasan dan pulang sebelum waktunya.

Dalam pengamatan awal ditemukan masih terdapat penyelesaian pekerjaan yang lamban, sehingga timbul teguran dari pimpinan yang lebih tinggi atau dari unit organisasi lain yang menanyakan penyelesaiaan atau jawaban atas surat-surat dan tugas-tugas lain yang belum terselesaikan secara tepat waktu. Kadang kala tugas-tugas rutin sering tertunda karena adanya tugastugas lain atau tambahan dari pimpinan yang lebih tinggi. Hal ini berdampak terhadap produktivitas kerja yang menurun

Peneliti menduga bahwa sementara ini masih kurangnya produktivitas pegawai disebabkan oleh lambannya penyelesaian kerja serta tugas lain yang harus segera diselesaikan erat kaitannya dengan kondisi pembagian kerja yang ada di lingkungan Badan Pendapatan Daerah Provinsi Banten. Pegawai yang sering datang terlambat, dapat disebabkan karena kondisi tempat tinggal dengan tempat kerja yang sangat jauh, namun di sisi lain, jauhnya tempat tinggal bukanlah satu-satunya alasan yang dijadikan untuk datang terlambat, namun penulis menduga karena faktor ketaatan yang kurang dan budaya organisasi yang kurang baik. Kurangnya ketegasan untuk memberikan dorongan agar pegawai datang tepat waktu dan memberikan sanksi terhadap pegawai yang indisipliner. Begitu pula terhadap pegawai yang sering meninggalkan tempat kerja, pulang sebelum waktunya dan tindakan-tindakan indisipliner lainnya, menurut dugaan penulis hal tersebut tidak terlepas dari budaya organisasi yang kurang baik. Selain itu penulis menduga, bahwa terdapat pegawai yang merasa jenuh dan bosan, karena ide-ide, prakarsa dan kemampuan yang ada tidak dapat disalurkan pada unit organisasinya, sehingga pegawai tersebut menyalurkan ide, bakat dan kemampuannya di tempat lain. 
Berdasarkan pengamatan penulis selain hal tersebut diatas terdapat juga permasalahan yang dihadapi oleh Badan Pendapatan Daerah Provinsi Banten yaitu dari segi kedisiplinan pegawai yang meliputi: pegawai sering tidak mengikuti apel pagi yang seharusnya dilakukan setiap hari sebelum pekerjaan dimulai dan tidak mengikuti apel sore dalam artian pulang lebih dahulu sebelum waktunya, pegawai sering mengulur waktu istirahat ataupun menggunakan waktu istirahat yang tidak sesuai dengan ketentuannya, pegawai sering datang terlambat dalam melakukan pekerjaan, dan beberapa pegawai sering tidak masuk bekerja atau izin tidak bekerja, dikarenakan kepentingan pribadi.

Berdasarkan Laporan Kinerja Instansi Pemerintah (LKIP) Badan Pendapatan Daerah Tahun Anggaran 2017 menunjukan bahwa prosentase realisasi pajak daerah keseluruhan sebesar Rp 5.487.328.744.008 $(99,67 \%)$ artinya pajak daerah yang diperoleh pada tahun anggaran 2017 tidak mencapai target. Hal ini dikarenakan tidak tercapainya realisasi pajak rokok (realisasi capaian pajak rokok pada TW.II telah memacu Badan Pendapatan Daerah Provinsi Banten untuk menaikan target pada $\mathrm{P}$ APBD Tahun anggaran 2017

Pembagian tugas/kerja yang tepat artinya tugas/kerja tersebut benar-benar ditangani oleh pegawai yang memenuhi syarat dalam bidang tersebut, sebab jika tidak ditangani oleh yang bukan ahlinya/bidangnya maka pekerjaan tersebut hasilnya tidak akan optimal.

Pembagian kerja kepada pegawai biasanya dicerminkan dengan deskripsi jabatan. Tujuan dari pembagian tugas tersebut adalah untuk mempermudah pelaksanaan berbagai macam kegiatan dalam instansi/lembaga. Dengan adanya pembagian kerja tersebut, pegawai akan bertanggung jawab terhadap pelaksanaan setiap

pekerjaan/kegiatan yang dibebankan kepadanya

Dalam pelaksanaan pembagian kerja ini masih ditemukan beberapa hal yang belum sesuai dengan ketentuan dikarenakan latarbelakang pendidikan dan penguasaan dalam hal-hal tertentu yang bukan bidang pekerjaannya. Berdasarkan hasil pengamatan sementara yang penulis lakukan menunjukkan bahwa adanya pembagian tugas yang tidak merata, sehingga ada pegawai yang terlihat sibuk, namun ada juga yang santai karena tidak mendapatkan tugas kerja dan masih terlihat adanya tumpang tindih pekerjaan karena tidak jelasnya pembagian kerja

Dengan memperhatikan uraian di atas, maka dalam penelitian ini akan memusatkan kajian kepada Pengaruh Disiplin Kerja, Budaya Organisasi dan Pembagian Kerja Terhadap Produktivitas Kerja Badan Pendapatan Daerah Provinsi Banten

\section{KAJIAN LITERATUR \\ Disiplin Kerja}

Disiplin kerja adalah suatu alat yang digunakan para pimpinan untuk berkomunikasi dengan pegawai agar mereka bersedia untuk mengubah suatu perilaku serta sebagai suatu upaya untuk meningkatkan kesadaran dan kesediaan seseorang mentaati semua peraturan organisasi dan norma-norma sosial yang berlaku (Veitzhal Rivai 2011:824). Disiplin pegawai memerlukan alat komunikasi, terutama pada peringatan yang bersifat spesifik terhadap pegawai yang tidak mau berubah sifat dan perilakunya.

Menurut Davis dalam

Mangkunegara (2011:129) : Disiplin dapat diartikan sebagai pelaksanaan 
manajemen untuk memperteguh pedoman-pedoman organisasi"

Sedangkan Veithzal Rivai (2011:825) disiplin kerja adalah suatu alat yang dipergunakan para manajer untuk berkomunikasi dengan pegawai agar mereka bersedia untuk mengubah suatu perilaku serta sebagai suatu upaya untuk meningkatkan kesadaran dan kesedian seorang dalam memenuhi segala peraturan organisasi.

Selanjutnya Singodimenjo dalam Edi Sitrisno (2011:86) disiplin adalah sikap kesediaan dan kerelaan seseorang untuk mematuhi dan mentaati norma-norma peraturan yang berlaku di sekitarnya.

Menurut Beach dalam Siagian (2012) sikap hormat terhadap peraturan dan ketetapan organisasi, yang ada dalam diri denga sukarela pada peraturan dan ketetapan organisasi.

Dari beberapa pengertian mengenai disiplin kerja di atas, penulis menyimpulkan bahwa disiplin timbul dari kesadaran pribadi seseorang untuk mengendalikan diri agar tidak melakukan sesuatu yang bertentangan dengan ketentuan yang berlaku. Hal ini dilakukan agar setiap individu dalam setiap organisasi mampu menhasilkan kinerja yang sesuai dengan apa yang diinginkan organisasi tersebut.

Adapun indikator menurut Singodimendjo dalam Sutrisno (2011:94) adalah sebagai berikut:

1. Taat terhadap aturan waktu

Dilihat dari jam masuk kerja, jam pulang, dan jam istirahat yang tepat waktu sesuai dengan aturan yang berlaku di organisasi

2. Taat terhadap peraturan organisasi Peraturan dasar tentang cara berpakaian, dan bertingkah laku dalam pekerjaan.

3. Taat terhadap aturan perilaku dalam pekerjaan
Ditunjukan dengan cara-cara melakukan pekerjaan-pekerjaan sesuai dengan jabatan, tugas dan tanggung jawab serta cara berhubungan dengan unit kerja lain.

4. Taat terhadap peraturan lainnya diorganisasi

Aturan tentang apa yang boleh dan apa yang tidak boleh dilakukan oleh para pegawai dalam organisasi.

\section{Budaya Organisasi}

Istilah Budaya (culture) berasal dari perkataan latin colere yang artinya mengolah, mengerjakan, menyuburkan, dan mengembangkan, terutama mengolah atau bertani. Atau bisa juga diartikan sebagai segala daya dan aktivitas untuk mengolah dan mengubah alam. Budaya merupakan nilai-nilai dan kebiasaan yang diterima sebagai acuan bersama yang diikuti dan dihormati.

Menurut

Mangkunegara (2005:113) Budaya kerja yang dikutip dari Edgar $H$. Schein mendefinisikan bahwa Budaya kerja adalah seperangkat asumsi atau sistem keyakinan, nilai-nilai dan norma yang dikembangkan dalam organisasi yang dijadikan pedoman tingkah laku bagi anggota-anggotanya untuk mengatasi masalah adaptasi eksternal dan integrasi internal.

Dalam rentang dua puluh tahun terakhir, topik budaya kerja menarik perhatian banyak orang, khususnya mereka yang mempelajari masalah perilaku kerja. Budaya kerja mulai dipandang sebagai sesuatu hal yang memiliki peranan penting dalam mencapai tujuan akhir suatu organisasi. Lingkungan yang berbeda akan memberi dampak pada pola dan warna budaya, karena itu terjadi pola dan warna budaya yang tebal dan tipis. Dalam budaya yang tebal terdapat kesepakatan yang tinggi dari anggotanya untuk mempertahankan apa yang diyakini benar dari berbagai 
aspek sehingga dapat membina keutuhan, loyalitas dan komitmen organisasi. Kesepakatan bersama ini diwariskan dari satu generasi ke generasi berikutnya. Jadi ada proses dalam mengadaptasi budaya kepada pegawai

$$
\text { Menurut Moeljono (2005: 2) }
$$

budaya kerja pada umumnya merupakan pernyataan filosofis, dapat difungsikan sebagai tuntutan yang mengikat pada pegawai karena dapat diformulasikan secara formal dalam berbagai peraturan dan ketentuan organisasi. Secara individu maupun kelompok seseorang tidak akan terlepas dari budaya yang ada dalam organisasi. Pada umumnya mereka akan dipengaruhi oleh keanekaragaman sumberdayasumberdaya yang ada sebagai stimulus sehingga seseorang dalam organisasi mempunyai perilaku yang spesifik bila dibandingkan dengan kelompok organisasi atau organisasinya.

Budaya kerja mempunyai dua tingkatan yaitu pada tingkatan yang lebih dalam dan kurang terlihat, budaya merujuk pada nilai-nilai yang dianut bersama oleh orang dalam kelompok dan cenderung bertahan sepanjang waktu. Pengertian ini mencakup tentang apa yang penting dalam kehidupan dan sangat bervariasi dalam organisasi yang berbeda. Pada tingkatan yang lebih terlihat, budaya menggambarkan pola atau gaya perilaku suatu organisasi, sehingga pegawai-pegawai baru secara otomatis terdorong untuk mengikuti perilaku sejawatnya

Sudah lama para ahli manajemen berusaha mendifinisikan budaya organisasi yang di kutip Ardana, dkk (2009:166) di antaranya adalah sebagai berikut .

1. Suatu persepsi bersama yang dianut oleh anggota suatu organisasi (Robbins, 2002)
2. Cara berpikir dan melakukan sesuatu yang mentradisi yang dianut bersama oleh semua anggota organisasi, dan para anggota baru harus mempelajari atau paling sedikit menerimanya sebagian agar mereka diterima sebagai bagian dari organisasi (Eliott Jaeques dalam Duncan, 1989).

3. Himpunan dari kepercayaan, harapan dan nilai yang dianut bersama oleh anggota organisasi dan diwariskan dari satu generasi ke generasi berikutnya (Wheelen dan Hunger 1988 dalam Nimran, 1997).

Budaya bisa dikatakan sebagai suatu sistem dari nilai bersama, yang akan dipakai sebagai pedoman dalam bertindak oleh anggota-anggota organisasi.

Menurut Schein (1992:21) berpendapat bahwa "an organization's culture is a pattern of basic assumptions invented, discovered or develoved by a given group as it learns to cope with its problems of external adaptation and internal integration that has worked well enouhgh to be considered valid and to be tauht to new members as the correct way to perceive, think and feel in relation to these problems. Berdasarkan pendapat itu dapat disimpulkan bahwa pengertian budaya organisasi adalah seperangkat asumsi atau sistem keyakinan, nilai-nilai dan norma yang dikembangkan dalam organisasi yang dijadikan pedoman tingkah laku bagi anggota-anggotanya untuk mengatasi masalah adaptasi eksternal dan integrasi internal.

Budaya telah menjadi konsep penting dalam memahami masyarakat dan kelompok manusia untuk waktu yang lama. Menurut Edward Taylor dalam Sobirin (2007:52) yaitu budaya adalah kompleksitas menyeluruh yang terdiri dari pengetahuan, keyakinan, 
seni, moral, hukum, adat kebiasaan dan berbagai kapabilitas lainnya serta kebiasaan apa saja yang diperoleh seorang manusia sebagai bagian dari sebuah masyarakat.

Menurut Robbins dalam Sobirin (2007:5), organisasi adalah unit sosial yang sengaja didirikan untuk jangka waktu yang relatif lama, beranggotakan dua orang atau lebih yang bekerja bersama-sama dan terkoordinasi, mempunyai pola kerja tertentu yang terstruktur, dan didirikan utnuk mencapai tujuan bersama atau satu set tujuan yang telah ditentukan sebelumnya.

Sedangkan menurut Bernard dalam Tika (2006:3) organisasi adalah kerja sama dua orang atau lebih, suatu sistem dari aktivitas-aktivitas atau kekuatan-kekuatan perorangan yang dikoordinasikan secara sadar. Budaya organisasi adalah norma-norma dan kebiasaan yang diterima sebagai suatu kebenaran oleh semua orang dalam organisasi. Budaya organisasi menjadi acuan bersama di antara manusia dalam berinteraksi dalam organisasi. Jika orang-orang bergabung dalam sebuah oraganisasi, mereka membawa nilai-nilai dan kepercayaan yang telah diajarkan kepada mereka.

Menurut Drucker dalam Tika (2006:4) mengatakan bahwa budaya organisasi adalah pokok penyelesaian masalah-masalah eksternal dan internal yang pelaksanaannya dilakukan secara konsisten oleh suatu kelompok yang kemudian diwariskan kepada anggota-anggota baru berbagai cara sebagai cara yang tepat untuk, memahami, memikirkan dan merasakan terhadap masalahmasalah terkait seperti diatas.

Menurut Tika (2008:5), unsurunsur yang terkandung dalam budaya kerja dapat diuraikan sebagai berikut :
1. Asumsi dasar

Dalam budaya kerja terdapat asumsi dasar yang dapat berfungsi sebagai pedoman bagi anggota maupun kelompok dalam organisasi untuk berperilaku.

2. Keyakinan yang dianut

Dalam budaya kerja terdapat keyakinan yang dianut dan dilaksanakan oleh para anggota organisasi. Keyakinan ini mengandung nilai-nilai yang dapat berbentuk slogan atau motto, asumsi dasar, tujuan umum organisasi, filosofi usaha, atau prinsip-prinsip menjelaskan usaha.

3. Pimpinan atau kelompok pencipta dan pengembangan budaya kerja.

Budaya kerja perlu diciptakan dan dikembangkan oleh pemimpin organisasi atau kelompok tertentu dalam organisasi tersebut.

4. Pedoman mengatasi masalah

Dalam organisasi, terdapat dua masalah pokok yang sering muncul, yakni masalah adaptasi eksternal dan masalah integrasi internal. Kedua masalah tersebut dapat diatasi dengan asumsi dasar dan keyakinan yang dianut bersama anggota organisasi.

5. Berbagai nilai (sharing of value)

Dalam budaya kerja perlu berbagi nilai terhadap apa yang paling diinginkan atau apa yang lebih baik atau berharga bagi seseorang.

6. Pewarisan (learning process)

Asumsi dasar dan keyakinan yang dianut oleh anggota organisasi perlu diwariskan kepada anggotaanggota baru dalam organisasi sebagai pedoman untuk bertindak dan berperilaku dalam organisasi tersebut.

7. Penyesuaian (adaptasi)

Perlu penyesuaian anggota kelompok terhadap peraturan atau norma yang berlaku dalam kelompok atau organisasi tersebut, 
serta adaptasi organisasi terhadap perubahan lingkungan.

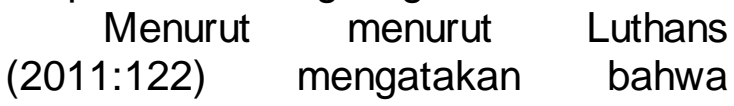
budaya organisasi didefinisikan sebagai berikut "Budaya organisasi merupakan norma-norma dan nilainilai yang mengarahkan perilaku anggota organisasi, dimana setiap anggota akan berperilaku sesuai dengan budaya yang berlaku agar diterima oleh lingkungannya".

Jadi dari pendapat ahli diatas dapat ditarik kesimpulan bahwa pengertian Budaya Organisasi adalah seperangkat asumsi atau keyakinan, nilai-nilai dan norma yang dikembangkan dalam organisasi yang dijadikan pedoman tingkah laku bagi anggota-anggotanya untuk mengatasi masalah adaptasi eksternal dan integrasi internal.

Yang menjadi dimensi dan indikator budaya organisasi menurut Luthans (2011:123) adalah:

1. Aturan Perilaku yang Diamati

Ketika anggota organisasi berinteraksi satu sama lain, mereka menggunakan bahasa, istilah, dan ritual umum yang berkaitan dengan rasa hormat dan cara berperilaku.

2. Norma

Ada standar perilaku, mencakup pedoman mengenai seberapa banyak pekerjaan yang dilakukan yang dalam perusahaan menjadi "jangan melakukan terlalu banyak, jangan terlalu sedikit"

3. Nilai Dominan

Organisasi mendukung dan berharap peserta membagikan nilai-nilai utama. Contoh kasusnya adalah kualitas produk tinggi, sedikit absen, dan efisiensi tinggi.

4. Filosofi

Terdapat kebijakan yang
membentuk
organisasi mengenai bagaimana
karyawan dan atau pelanggan
diperlakukan

5. Aturan

Terdapat pedoman ketat berkaitan dengan pencapaian perusahaan. Pendatang baru harus mempelajari teknik dan prosedur yang ada agar diterima sebagai anggota kelompok yang berkembang.

6. Iklim organisasi

Ini merupakan keseluruhan perasaan yang disampaikan dengan pengaturan yang bersifat fisik, cara bekerja berinteraksi, dan cara anggota organisasi berhubungan dengan pelanggan dan individu dari luar.

\section{Pembagian Kerja}

Dalam menguraikan tentang konsep pembagian kerja terlebih dahulu diawali dengan menjelaskan tentang organisasi. Hal ini dikarenakan organisasi merupakan sarana atau alat untuk mencapai tujuan, oleh karena itu dapat dijelaskan bahwa organisasi merupakan wahana kegiatan dari orang-orang yang bekerjasama dalam usahanya mencapai tujuan. Dalam organisasi harus jelas mengenai tugas, wewenang dan tanggung jawabnya serta hubungan dan tata kerjanya.

Sehubungan dengan uraian di atas, Sudjadi (2008:4) mengemukakan "Pengorganisasian merupakan proses penyusunan pembagian kerja ke dalam unit-unit kerja dan fungsifungsinya (staffing) yang harus menduduki fungsi-fungsiitu berikut penentuannya dengan tept tentang hubungan wewenang dan tanggung jawab".

Berdasarkan pendapat tersebut, pembagian kerja mempunyai dua macam arti yaitu dapat dihubungkan dengan satuan organisasi dan dapat pula dihubungkan dengan pejabatnya. Apabila dihubungkan dengan organisasi, pembagian kerja adalah rincian serta pengelompokkan aktivitas-aktivitas semacam atau erat 
hubungannya satu sama lain untuk dilaksanakan satuan organisasi. Sedangkan apabila dihubungkan dengan pejabat, pembagian kerja adalah rincian serta pengelompokkan tugas-tugas semacam atau erat hubungannya satu sama lain untuk dilakukan oleh seorang pejabat/pegawai.

Menurut Siagian (2012:9), ada tiga sebab mengapa pembagian kerja harus terjadi, yaitu:

1. Beban kerja yang harus dipikul

Beban dan volume kerja merupakan kosekuensi logis dari fungsi yang beraneka rgam yang harus dilaksanakan.

2. Jenis pekerjaan yang beraneka ragam

Jenis pekerjaan yang beraneka ragam merupakan konsekuensi dari fungsi-fungsi yang menjadi tanggung jawab untuk dilaksanakan.

3. Bebagai spesilisasi yang diperlukan

Beban kerja dan jenis pekerjaan yang beraneka ragm memerlukan spesialisasi pula.

Sedangkan Gullick dalam (Sutarto, 2010:104) menyatakan alasan-alasan pembagian kerja sebagai berikut:

1. Karena orang berbeda dalam pembawaan, kemampuan serta kecakapan dalam mencapai ketangkasan yang besar dengan spesialisasi.

2. Karena orang yang sama tidak dapat berada di dua tempat pada saat yang sama.

3. Karena orang tidak dapat mengerjakan dua hal pada saat yang sama.

4. Karena bidang pengetahuan dan keahlian begitu luas sehingga seseorang dalam rentang hidupnya tidak mungkin dapat mengetahui lebih banyak daripada sebagian sangat kecil dari padanya.
Usaha yang dilakukan dalam pencapaian tujuan organisasi, tidak dapat dipisahkan dengan pengaturan kegiatan-kegiatan atau tugas-tugas yang harus diselesaikan oleh aparat organisasi tersebut, untuk melaksanakan hal tersebut maka diperlukan adanya pengaturan mengenai prinsip kerja.

Sehubungan dengan pendapat di atas, Sukarna (2009:9) menyatakan pendapatnya bahwa "Didalam setiap pembagian kerja antara pegawai harus memperhatikan kualitas, fisik, moral, mental, pendidikan dan pengalaman. Hendaknya jangan pegawai yang tidak berpengalaman dan kurang cerdas ditempatkan pada bagian kerja yang banyak membutuhkan pemikiran dan keahlian. Pembagian kerja yang disesuaikan dengan kemampuan dan keahlian masing-masing pegawai akan menimbulkan rasa senang bekerja dan bertanggung jawab, sehingga pelaksanaan pekerjaan itu berjalan dengan efektif dan berdisiplin. Pembagian kerja yang baik merupakan kunci bagi penyelenggaraan kerja sebaikbaiknya. Dan kecerobohan dalam pembagian kerja akan mempunyai pengaruh yang kurang baik bahkan mungkin menimbulkan kegagalan dalam penyelenggaraan pekerjaan"

Dari uraian tersebut di atas dapat dijelaskan bahwa dalam setiap pembagian kerja harus memperhatikan kualitias, fisik, moral, mental, pendidikan dan pengalaman; hendaknya pegawai yang tidak berpengalaman dan kurang cerdas tidak ditempatkan pada bagian kerja yang banyak membutuhkan pemikiran dan keahlian; pembagian kerja disesuaikan dengan kemampuan dan keahlian masing-masing pegawai akan menimbulkan rasa senang bekerja dan bertanggung jawab, sehingga pelaksanaan pekerjaan itu berjalan dengan baik dan berdisiplin. 
Pembagian kerja mempunyai arti penting dalam proses pencapaian tujuan organisasi, sehingga dalam melaksanakan prinsip pembagian kerja tersebut perlu memahami beberapa aturan sebagai dasar untuk megatur aktivitas-aktivitas dan tugastugas organisasi serta penentuan orang-orang yang akan melaksanakan aktivitas-aktivitas tersebut secara adil dan merata.

Adapun tujuan dari pembagian kerja atau tata kerja menurut pendapat FX. Soedjadi (2008 : 13) adalah sebagai berikut :

1. Menghindarkan terjadinya pemborosan didalam pendayagunaan faktor-faktor tenaga kerja, biaya, material, waktu dan sebagainya.

2. Menghindarkan kemacetankemacetan dan kesimpang siuran dalam proses pencapaian tujuan.

3. Menjamin adanya pembagian kerja, pembagian waktu, dan koordinasi yang setepat-tepatnya. Menurut Sutarto (2010:126) dimensi dari pembagian kerja adalah :

1. Perincian aktivitas tiap satuan organisasi.

2. Perincian aktivitas tiap pegawai

3. Jumlah tugas

4. Variasi tugas

5. Beban tugas

6. Penempatan pegawai

7. Penambahan dan pengurangan pegawai

8. Pembagian/perincian tugas

9. Penggolongan tugas

\section{Produktivitas Kerja}

Menurut Tohardi (2002) dalam Sutrisno (2012:100), mengemukakan bahwa produktivitas kerja merupakan sikap mental. Sikap mental yang selalu mencari perbaikan terhadap apa yang telah ada. Suatu keyakinan bahwa seseorang dapat melakukan pekerjaan lebih baik hari ini daripada hari kemarin dan hari esok lebih baik hari ini.

Sedangkan menurut pendapat tersebut didukung oleh Ravianto (1991) dalam Sutrisno (2012:100), mengatakan bahwa produktivitas pada dasarnya mencakup sikap mental yang selalu mempunyai pandangan bahwa kehidupan hari ini harus lebih baik dari hari kemarin dan hari esok harus lebih baik dari hari ini. Sikap yang demikian akan mendorong seseorang untuk tidak cepat merasa puas, akan tetapi harus mengembangkan diri dan meningkatkan kemampuan kerja dengan cara selalu mencari perbaikanperbaikan dan peningkatan.

Menurut Washin (1997) yang diterjemahkan oleh Saksono dalam Badriyah (2015:183) mengatakan bahwa produktivitas mengandung dua konsep utama, yaitu efisiensi dan efektivitas. Efisiensi mengukur tingkat sumber daya, baik manusia, keuangan, maupun alam yang dibutuhkan untuk memenuhi tingkat pelayanan yang dikehendaki, efektivitas mengukur hasil mutu pelayanan yang dicapai

Sedangkan menurut Sinungan (2001) dalam Badriyah (2015:183) mengatakan bahwa produktivitas adalah pendekatan intradisipliner untuk menentukan tujuan yang efektif, pembuatan rencana, aplikasi penggunaan cara yang produktif untuk menggunakan sumber secara efisien dan tetap menjaga adanya mutu yang tinggi

Berdasarkan

pengertianpengertian di atas, jelas bahwa produktivitas merupakan perbandingan antara hasil kerja dengan bahan, waktu, dan tenaga yang digunakan dalam memproduksi barang atau jasa dengan menggunakan sumber-sumber yang ada secara efektif dan efisien, tetapi tetap menjaga mutu barang atau jasa yang dihasilkan. 


\section{METODE PENELITIAN}

Metode yang digunakan adalah metode kuantitatif, dengan rumusan masalah asosiatif dan pendekatan atau kerangka pemikiran paradigma ganda dengan tiga variabel independen yang diduga sebagai variabel paling dominan mempengaruhi Produktivitas Kerja, yaitu Disiplin Kerja, Budaya Organisasi dan Pembagian Kerja

Populasi dalam penelitian ini adalah seluruh pegawai Badan Pendapatan Daerah Provinsi Banten yang berjumlah 80 orang. Jumlah sampel setelah dikurangi Kepala Badan Pendapatan Daerah Provinsi Banten dan peneliti jadi total sampel sebanyak 78 orang.

\section{HASIL PENELITIAN DAN PEMBAHASAN}

Penelitian ini untuk mengetahui pengaruh disiplin kerja, budaya organisasi dan pembagian kerja secara bersama-sama terhadap produktivitas kerja Badan Pendapatan Daerah Provinsi Banten

1. Pengaruh disiplin kerja terhadap produktivitas kerja Badan Pendapatan Daerah Provinsi Banten

Dari deskripsi data setelah dilakukan analisis korelasi diperoleh nilai korelasi sebesar 0,748 dan koefisien determinasi sebesar $15,3 \%$, setelah dilakukan pengujian dengan program SPSS versi 24 terbukti bahwa koefisien korelasi tersebut signifikan. Hal ini berarti bahwa terdapat pengaruh disiplin kerja terhadap produktivitas kerja Badan Pendapatan Daerah Provinsi Banten

Setelah dilakukan pengujian liniearitas garis regresi dengan menggunakan program SPSS diperoleh bahwa garis regresi linier. Dari pengujian signifikansi koefisien regresi yang juga dilakukan dengan program SPSS tersebut diperoleh bahwa koefisien regresi tersebut signifikan, yang berarti benar bahwa terdapat pengaruh yang signifikan disiplin kerja terhadap produktivitas kerja Badan Pendapatan Daerah Provinsi Banten

Nilai $\operatorname{Sig}=0,005<0,05$ dan $t_{\text {hitung }}(2,891)>t_{\text {tabel }}(1,671)$, maka $\mathrm{H}_{0}$ di tolak yang berarti terdapat pengaruh yang signifikan disiplin kerja $\left(X_{1}\right)$ terhadap produktivitas kerja ( $\mathrm{Y}$ ) Badan Pendapatan Daerah Provinsi Banten

Menurut sintesis teori yang ada di bab II, Hasil penelitian ini sesuai dengan pernyataan menurut Sutrisno (2011:94) dengan dimensi antara lain taat terhadap aturan waktu, taat terhadap peraturan organisasi, taat terhadap aturan perilaku dalam pekerjaan, dan taat terhadap peraturan lainnya di organisasi

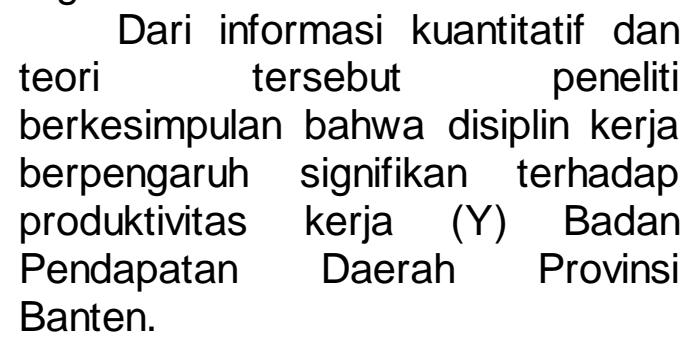

2. Pengaruh budaya organisasi terhadap produktivitas kerja Badan Pendapatan Daerah Provinsi Banten

Dari deskripsi data setelah dilakukan analisis korelasi diperoleh nilai korelasi sebesar 0,879 dan koefisien determinasi sebesar $49,8 \%$, setelah dilakukan pengujian dengan program SPSS versi 24 terbukti bahwa koefisien korelasi tersebut signifikan. Hal ini berarti bahwa terdapat pengaruh budaya organisasi terhadap produktivitas kerja Badan Pendapatan Daerah Provinsi Banten 
Setelah dilakukan pengujian liniearitas garis regresi dengan menggunakan program SPSS diperoleh bahwa garis regresi linier. Dari pengujian signifikansi koefisien regresi yang juga dilakukan dengan program SPSS tersebut diperoleh bahwa koefisien regresi tersebut signifikan, yang berarti benar bahwa terdapat pengaruh yang signifikan budaya organisasi terhadap produktivitas kerja Badan Pendapatan Daerah Provinsi Banten

Nilai $\operatorname{Sig}=0,000<0,05$ dan $t_{\text {hitung }}(7,021)>t_{\text {tabel }}(1,671)$, maka $\mathrm{H}_{0}$ di tolak yang berarti terdapat pengaruh yang signifikan budaya organisasi $\left(\mathrm{X}_{2}\right)$ terhadap produktivitas kerja (Y) Badan Pendapatan Daerah Provinsi Banten

Menurut sintesis teori yang ada di bab II, Hasil penelitian ini sesuai dengan pernyataan menurut Luthans (2011:123) dengan dimensi antara lain aturan perilaku yang diamati, norma, nilai Dominan, filosofi, aturan, dan iklim organisasi

Dari informasi kuantitatif dan teori tersebut peneliti berkesimpulan bahwa budaya organisasi berpengaruh signifikan terhadap produktivitas kerja Badan Pendapatan Daerah Provinsi Banten

\section{Pengaruh pembagian kerja terhadap produktivitas kerja Badan Pendapatan Daerah Provinsi Banten}

Dari deskripsi data setelah dilakukan analisis korelasi diperoleh nilai korelasi sebesar 0,806 dan koefisien determinasi sebesar $17,7 \%$, setelah dilakukan pengujian dengan program SPSS versi 24 terbukti bahwa koefisien korelasi tersebut signifikan. Hal ini berarti bahwa terdapat pengaruh pembagian kerja terhadap produktivitas kerja Badan Pendapatan Daerah Provinsi Banten

Setelah dilakukan pengujian liniearitas garis regresi dengan menggunakan program SPSS diperoleh bahwa garis regresi linier. Dari pengujian signifikansi koefisien regresi yang juga dilakukan dengan program SPSS tersebut diperoleh bahwa koefisien regresi tersebut signifikan, yang berarti benar bahwa terdapat pengaruh yang signifikan pembagian kerja terhadap produktivitas kerja Badan Pendapatan Daerah Provinsi Banten

Nilai $\operatorname{Sig}=0,009<0,05$ dan $t_{\text {hitung }}(2,669)>t_{\text {tabel }}(1,671)$, maka $\mathrm{H}_{0}$ di tolak yang berarti terdapat pengaruh yang signifikan pembagian kerja $\left(X_{3}\right)$ terhadap produktivitas kerja (Y) Badan Pendapatan Daerah Provinsi Banten

Menurut sintesis teori yang ada di bab II, Hasil penelitian ini sesuai dengan pernyataan menurut Sutarto (2010:126) dengan dimensi antara lain perincian aktivitas tiap satuan organisasi, perincian aktivitas tiap pegawai, jumlah tugas, variasi tugas, beban tugas, penempatan pegawai, penambahan dan pengurangan pegawai, pembagian/perincian tugas, dan penggolongan tugas

Dari informasi kuantitatif dan teori tersebut peneliti berkesimpulan bahwa pembagian kerja berpengaruh signifikan terhadap produktivitas kerja Badan Pendapatan Daerah Provinsi Banten 
4. Pengaruh disiplin kerja, budaya organisasi dan pembagian kerja secara bersama-sama terhadap produktivitas kerja Badan Pendapatan Daerah Provinsi Banten

Dari deskripsi data setelah dilakukan analisis korelasi diperoleh nilai korelasi sebesar 0,910 dan koefisien determinasi sebesar $82,9 \%$, setelah dilakukan pengujian dengan program SPSS versi 24 terbukti bahwa koefisien korelasi tersebut signifikan. Hal ini berarti bahwa terdapat pengaruh disiplin kerja, budaya organisasi dan pembagian kerja secara bersama-sama terhadap produktivitas kerja Badan Pendapatan Daerah Provinsi Banten

Sedangkan dari analisis regresi diperoleh persamaan garis regresi

$Y=1,391+0,221 X_{1}+0,503 X_{2}+0,213 X$ 3 Nilai konstanta $=1,391$ menunjukan bahwa dengan disiplin kerja, budaya organisasi dan pembagian kerja, maka produktivitas kerja pegawai Badan Pendapatan Daerah Provinsi Banten dapat meningkat, sedangkan nilai regresi sebesar $0,221, \quad 0,503$ dan 0,213 menunjukan bahwa terdapat terdapat pengaruh positif disiplin kerja, budaya organisasi dan pembagian kerja secara bersamasama terhadap produktivitas kerja Badan Pendapatan Daerah Provinsi Banten. Angka koefisien regresi tersebut juga menunjukan bahwa setiap kenaikan satu nilai disiplin kerja maka akan terdapat kenaikan produktivitas kerja Badan Pendapatan Daerah Provinsi Banten sebesar 0,221, untuk budaya organisasi setiap ada kenaikan satu nilai budaya organisasi maka akan terdapat kenaikan produktivitas kerja Badan Pendapatan Daerah Provinsi Banten sebesar 0,503, sedangkan untuk pembagian kerja setiap ada kenaikan satu nilai pembagian kerja maka akan terdapat kenaikan produktivitas kerja Badan Pendapatan Daerah Provinsi Banten sebesar 0,213. Semuanya dalam keadaan cateris paribus.

Setelah dilakukan pengujian liniearitas garis regresi dengan menggunakan program SPSS diperoleh bahwa garis regresi linier. Dari pengujian signifikansi koefisien regresi yang juga dilakukan dengan program SPSS tersebut diperoleh bahwa koefisien regresi tersebut signifikan, yang berarti benar bahwa terdapat pengaruh yang signifikan disiplin kerja, budaya organisasi dan pembagian kerja secara bersamasama terhadap produktivitas kerja Badan Pendapatan Daerah Provinsi Banten

$$
\text { Nilai } \mathrm{Sig}=0.000<0,05 \text { dan }
$$

$F_{\text {hitung }}(119,461)>F_{\text {tabel }}(3,58)$, maka $\mathrm{H}_{0}$ di tolak yang berarti bahwa koefisien regresi tersebut signifikan. Berarti bahwa terdapat pengaruh signifikan disiplin kerja, budaya organisasi dan pembagian kerja secara bersama-sama terhadap produktivitas kerja Badan Pendapatan Daerah Provinsi Banten

Menurut sintesis teori yang ada di bab II, Hasil penelitian ini sesuai dengan pernyataan menurut Simamora (2014:612) dengan dimensi antara lain kuantitas kerja, kualitas kerja dan ketepatan waktu

Dari informasi kuantitatif dan teori tersebut peneliti berkesimpulan bahwa disiplin kerja, budaya organisasi dan pembagian kerja secara bersama-sama berpengaruh signifikan terhadap produktivitas kerja Badan 
Pendapatan Daerah Provinsi Banten

\section{KESIMPULAN}

Berdasarkan penyajian dan analisis hasil penelitian maka dapat ditarik kesimpulan bahwa

1. Besarnya pengaruh signifikan disiplin kerja terhadap produktivitas kerja pada Badan Pendapatan Daerah Provinsi Banten sebesar $15,3 \%$

2. Besarnya pengaruh signifikan budaya organisasi terhadap produktivitas kerja pada Badan Pendapatan Daerah Provinsi Banten sebesar $49,8 \%$

3. Besarnya pengaruh signifikan pembagian kerja terhadap produktivitas kerja pada Badan Pendapatan Daerah Provinsi Banten sebesar $17,7 \%$

4. Besarnya pengaruh signifikan disiplin kerja, budaya organisasi dan pembagian kerja secara bersama-sama terhadap produktivitas kerja pada Badan Pendapatan Daerah Provinsi Banten sebesar $82,9 \%$ sisanya $17,1 \%$ merupakan faktor lain yang tidak diteliti

\section{SARAN}

Berdasarkan hal tersebut penulis mengemukakan beberapa saran antara lain sebagai berikut :

1. Pimpinan Badan Pendapatan Daerah Provinsi Banten agar mengawasi pegawai supaya setiap hari datang dan pulang bekerja sesuai dengan jam kerja yang telah ditentukan, agar tingkat disiplin kerja pegawai menjadi meningkat yang berdampak pada produktivitas yang tinggi

2. Pimpinan Badan Pendapatan Daerah Provinsi Banten harus selalu berusaha mempengaruhi para pegawai atau bawahan agar selalu bekerja bersama-sama supaya pekerjaan menjadi lebih ringan dan cepat dalam penyelesaiannya

3. Pemberian tugas/pekerjaan oleh pimpinan Badan Pendapatan Daerah Provinsi Banten kepada pegawai harus dibagi dan dilaksanakan secara merata agar tidak terjadi kecemburuan sosial dan pegawai bekerja sesuai tupoksi bidang masing-masing

4. Pegawai Badan Pendapatan Daerah Provinsi Banten agar selalu berusaha menyelesaikan pekerjaan sesuai dengan waktu yang telah ditentukan, karena dengan demikian produktivitas kerja pegawai dapat tercapai dengan hasil yang optimal

\section{DAFTAR PUSTAKA}

Anggara, Sahya. 2012. IImu Administrasi Negara. Bandung : CV. Pustaka Setia

Arikunto, Suharsimi. 2008. Prosedur Penelitian Suatu Pendekatan Praktik. Jakarta : PT. Rineka Cipta.

Darsono $\mathrm{P}$ dan Siswandoko, Tjatjuj. 2011. Manajemen Sumber Daya Manusia. Jakarta : Nusantara Consulting.

Dewi, Irra Chrisyanti. 2011. Manajemen Perkantoran. Jakarta : PT. Prestasi Pustakaraya

Effendy, Onong Uchjana. 2010. IImu Komunikasi Teori dan Praktek. Bandung : PT. Remaja Rosdakarya.

Engkoswara \& Komariah, Aan. 2010. Administrasi Pendidikan. Bandung : CV Alfabeta

Handayaningrat, Soewarno. 2011. Pengantar Studi IImu Administrasi dan Manajemen. Jakarta : Haji Masagung.

Handoko, T Hani. 2013. Manajemen. Yogyakarta : BPFE Yogyakarta.

Hasibuan, Malayu S.P. 2011. Manajemen Sumber Daya 
Manusia. Jakarta : PT. Bumi Aksara.

2008. Manajemen Sumber Daya Manusia. Jakarta : PT. Bumi Aksara.

2014. Manajemen, Dasar, Pengertian, dan Masalah. Jakarta : PT. Bumi Aksara.

Luthans, Fred. 2011. Organizational Behaviour : An Evidence-Based Approach. New York. McGrawHill

Manullang, M. 2008. Dasar-dasar Manajemen. Yogyakarta : Gadjah Mada University Press.

Muhidin, Sambas Ali \& Abdurahman, Maman. 2008. Analisis Korelasi, Regresi, dan Jalur dalam Penelitian. Bandung : CV. Pustaka Setia

Mulyadi, Mohammad. 2014. Metode Penelitian Praktis Kuantitatif dan Kualitatif. Jakarta : Publica Institut

Pasolong, Harbani. 2013. Metode Penelitian Administrasi Publik. Bandung CV. Alfabeta

Siagian, Sondang P. 2014. Filsafat Administrasi. Jakarta : PT. Bumi Aksara

Silalahi, Ulber. 2011. Asas-asas Manajemen. Bandung : PT. Refika Aditama

Syafi'ie, Inu Kencana. 2009. Sistem Administrasi Negara Republik Indonesia (SANRI). Jakarta : PT. Bumi Aksara

Syafri, Wirman. 2012. Studi tentang Administrasi Publik. Jakarta : Erlangga
Wiludjeng, Sri. 2008. Pengantar Manajemen. Yogyakarta : Graha IImu

JURNAL :

Annisa, Rullie. 2013. Pengaruh gaya kepemimpinan dan komitmen organisasi terhadap budaya kerja dalam meningkatkan produktivitas kerja pada Dinas PU CK\&TR. Jurnal

Rahadian, A. H. dan Kencana, Mila. 2016. Pengaruh disiplin dan motivasi kerja pegawai terhadap efektivitas kerja penanggulangan bencana alam di Kecamatan Sukamakmur Kabupaten Bogor. Jurnal

Rahadian, A. H. Dkk. 2018. Pengaruh kompetensi pegawai dan iklim organisasi terhadap kualitas pelayanan di Unit Pelaksana Pelayanan Terpadu Satu Pintu Kota Administrasi Jakarta Barat. Jurnal

Setiawan, Yana, 2010. Pengaruh gaya kepemimpinan dan budaya organisasi terhadap produktivitas kerja pegawai Dinas Olah Raga dan Pemuda Provinsi Jawa Barat. Jurnal

Zebua, Martin. 2017. Pengaruh gaya kepemimpinan terhadap produktivitas kerja pegawai pada PT. Coca-Cola Cabang Malang. Jurnal 